\title{
Corporate social responsibility disclosure quality and analyst forecast
}

\author{
Jing Jiao ${ }^{1, a}$, Chunhyun Nam ${ }^{2, b}$ \\ ${ }^{1}$ School of business, The University of Suwon, Suwon 16200, Korea; \\ ${ }^{1}$ School of business, Linyi University, Linyi 276000 , China; \\ ${ }^{2}$ School of business, The University of Suwon, Suwon 16200, Korea. \\ ajj668@163.com, ${ }^{b}$ chnam37@naver.com
}

\begin{abstract}
The study examines the relationship between corporate social responsibility (csr) disclosure quality and sell-side analyst forecast error and optimism using multi-level capital markets in China. Results suggest that csr disclosure quality contributes to decrease analyst forecast error and optimism; furthermore, the lagged effect of csr disclosure quality in previous year is stronger. Listed companies published csr reports in main board, sme board and gem board comply with completely distinct listing restrictions and transaction systems, which leads to heterogeneity and empirically tests that random effect model is superior to fixed effect model and pooled ols model in multi-level capital markets inconsistent with prior studies.
\end{abstract}

Keywords: corporate social responsibility; analyst forecast error; analyst forecast optimism

\section{Introduction}

Corporate social responsibility (csr) in emerging markets still acknowledged as a new issue deserves greater attention to reduce commonly characterized information asymmetry than in developed capital markets. The relationship between csr disclosure quality and sell-side analyst forecasts is an important topic in the academic and practical domains (e.g., Lang and Loundholm 1996; Hope 2003; Vanstraelen et al., 2003; Behn et al., 2008; Dhaliwal et al.,2012; Li et al., 2014). The primary objectives of the research are to examine the impact of csr disclosure quality on sell-side analyst forecasts and shed some light on addressing the underlying relationships between the two issues in the publicly listed companies in China.

Csr disclosure information is provided by the third leading csr rating agency-rankins csr ratings (rks). We are supposed to choose superior methodology among pooled ols, fixed effect and random effect according to unbalanced short panel data (lagged csr) and balanced short panel data (contemporaneous csr).

Empirical results support of the recently literatures emphasized on current csr disclosure effect on current analyst forecast. We find that csr disclosure quality helps to decrease analyst forecast error and optimism. We expect similar consequences based on the effect of csr disclosure quality in previous year on analyst forecast as well as in contemporaneous year. Evidence shows the effect of csr disclosure quality in previous year is more significant.

Carried out f-test, bp-lm test and hausman test, we indicate that individual effects exist in multi-level capital markets in China. Owing to heterogeneity of all listed companies published csr reports we find random effect model is superior to fixed effect model and pooled ols model.

Our study contributes to the unpublished literature on analyst forecast by identifying and providing evidence that $c s r$ disclosure information in previous year has a negative association with the forecast error and optimism.

Prior studies focus on the implications of current csr information on current analyst forecasts, but we would like to test whether csr information in previous year affects analyst forecasts. Whether it is possible if listed firms continue to engage in corporate social responsibility activities will attract more analysts following. Whether analysts are concerned about past csr activities and 
announce their recommendation referring to csr information in previous year.

We also extend research methodology on csr activities. Prior studies apply fixed effect model or pooled ols model. There are multi-level capital markets in China, which are main board, small and medium enterprises (sme) board and growth enterprises market (gem) board, to serve diverse investors and financiers. Sme board and gem board aim to reform capital markets and fund growth in the private sector. More and more listed companies in China disclose corporate social responsibility information; we include all the listed firms belonging to different boards to do analyses.

The remainder of this paper is organized as follows. In Section 2, we introduce related research and develop our hypotheses. We explain the sample, variables and research design in Section 3. Section 4 presents the empirical results and section 5 shows the robustness test. Section 6 concludes the paper.

\section{Related research and hypothesis development}

Based on Friedman's (1970) famous controversial article, business has only one social responsibility that is to use resources and designed activities to increase profits, which triggers more intellectual interest in what is the real corporate social responsibility. Baron et al. (2000) argues that competent executives are able to integrate market strategies with non-market strategies in order to position their firms for optimal effectiveness. What are the financial consequences according to the information integration, especially the $c s r$ information integration? Our study is related to research examining the association between csr activities and financial consequences including analyst forecasts.

\section{1 csr and financial consequences}

Accounting to stakeholder theory, effective management of stakeholder relationships leads to better financial performance. Asymmetry information reduces financial transparency and management efficiency. Researchers and practitioners show interest in firms' disclosure practices and find evidence supporting increased disclosure may mitigate the information asymmetry between informed and uninformed investors (Baginski and Hassell, 1990). Lang and Lundholm (1996) suggest that the potential benefits of disclosure include reduced estimation risk and reduced information asymmetry. Nonfinancial information disclosures, especially $c s r$ issues increase financial communications to investors (Gelb and Strawser, 2001; Fieseler, 2011). Such literatures include but are not limited to: cost of capital; firm risk; market value; analyst recommendation and analyst following; customer satisfaction and so on.

The potential benefits of disclosure reduce information asymmetry and cost of capital, which are likely to receive increased investor following and stock liquidity, accurate market expectations, all of which lead to a lower cost of capital for the firms (Lang and Lundholm, 1996; Healy et al., 1999; Holder-Webb et al., 2009). The univariate results of study on ethical corporate citizenship and financial performance indicate a significant relationship between them, with greater profitability and efficiency, and lower cost of capital (Blazovich and Murphy Smith, 2011). Firms exploit the benefit of a lower cost of equity capital associated with the initiation of stand-alone csr disclosure (Dhaliwal et al., 2011).

Executives interested in the financial impact of social responsibility might look toward reduced risk (McGuire et al., 1988). Nichols and Wieland (2009) confirm nonfinancial disclosures provide credible and value-relevant information and reduce the uncertainty about future earnings. Jo and Harjoto (2014) find that the change in csr engagement as well as the interaction effect of changes in csr and analyst coverage reduces the change of firm risk. Firms with low risk may be better able to afford to act in a socially responsible manner (McGuire et al., 1988). Therefore, the market valuation of ethical firms is associated with better financial performance and lower risk (Blazovich and Murphy Smith, 2011).

Socially responsible firms are likely to drive managers to create more market value and deliver high-quality financial reports to investors (Kim and Venkatachalam, 2011), especially with larger firm size (Trotman and Bradley, 1981; Holder-Webb et al., 2009). Gelb and Strawser (2001) find a positive relationship between the disclosures of firms and csr. Significant charitable contributions by 
award winners may be indicative of a sound business strategy to maximize long-term firm value (Yoo and Pae, 2016). Ioannou and Serafeim (2010, 2015) find socially responsible firms receive more favorable analysts' investment recommendation, with analysts' recommendation csr strategies impact value creation in public equity markets. Existing empirical research complements that firms with relatively good reputations and certain socially responsible investing are better able to sustain and enhance superior profit outcomes over time (Roberts and Dowling ,2002 ; Edmans, 2011) and market value (Yeh et al., 2011).

In support of the good management mechanism, Kang et al. (2016) suggest that firms that engage in corporate social responsibility are likely to benefit financially from their csr investments. Applying Granger causality tests, Lev et al. (2009) examine the impact of corporate charitable contributions on future revenue and find significantly association. Csr associations have a significantly positive influence on consumer responses to products; in addition, csr associations improve the brand value and firm reputation and enhance the product evaluation (Brown and Dacin, 1997). Welfare-oriented companies invest csr activities serving as a signal for superior product quality (Fisman et al., 2006) and more attractive working environment to job seekers (Boudreau and Rynes, 1985; Ashforth and Mael, 1989; Gugler and Shi, 2009). More socially responsible firms yield competitive advantages to attract/retain customers and enhance customer satisfaction than less socially responsible peers (Lev et al., 2009; Holbrook, 2014).

Wang et al. (2016) provide an overview of csr research published in academy of management journal over nearly six decades and conclude that there is a conceptual shift from financial consequences to non-financial, social, and organizational consequences.

\section{2 csr disclosure and analyst forecast}

Prior research examines the relations between csr and financial consequences provided by different capital markets. Relative to other financial consequences, research reveals how analysts respond to nonfinancial information disclosure especially csr disclosure is scarce. Financial analysts are an indispensable part in capital market (Covrig and Low, 2005; Holland and Johanson, 2003), consistent with existing evidence that analysts are crucial information intermediaries (Chen et al., 2010; Healy and Palepu, 2001; Livnat and Zhang, 2012). Sell-side analysts recommend brokers, managers, institutional investors and other stakeholders to achieve their expected goals and maximize utility. Jo and Harjoto (2014) maintain that analysts provide indirect but additional social pressure to the firms to eventually reduce their irresponsible activities.

Analyst forecast properties and characteristics being investigated in our study are forecast accuracy and optimism in analyst forecasts process (e.g., Lang and Lundholm, 1996; Barron et al., 1999; Holbrook, 2014; Calderon, 1993).

\subsection{1 csr disclosure quality and analyst forecast error}

Nichols and wieland (2009) document that analysts' forecasts revised to nonfinancial information become more accurate and forecast error declines when companies issue nonfinancial disclosures. Lang and Lundholm (1996) investigate the association between disclosure policy and analyst forecast accuracy, which suggests that analyst forecasts respond to disclosure policy. Increased disclosure is associated with increases in analyst following and forecast accuracy, reductions in forecast errors. Evidences indicate that improved firm csr disclosure has larger analyst following and accuracy, but analyst forecast error varies inversely with the quality of a broad set of disclosures (Lang and Lundholm, 1996; Behn et al., 2008).

Using firm-level data from 31 countries, Dhaliwal et al. (2012) examine the relationship between stand-alone csr reports and analyst forecast accuracy. They demonstrate that the issuance of stand-alone csr reports is associated with earnings forecast accuracy and significantly negatively with analysts' forecast errors especially in stakeholder-oriented countries.

Li et al. (2014) examine the relationship between stand-alone csr reports disclosure and analyst forecast accuracy in shenzhen stock exchange in China, then analyze panel data using multi regression and show there is a significantly positive association.

Summarizing the analyst forecast properties related to csr disclosure, past studies support a significant association between current csr disclosure quality and current analyst forecast errors. We 
state the prediction consistent with prior studies:

H1: Ceteris paribus, contemporaneous csr disclosure quality decreases current analyst forecast error.

With the assumption of profit-oriented goals, listed companies prefer to maximize profits driven only by their self-interest. However, theoretical literatures consider csr as detached from the goal of profit maximization. Social and environmental activities help to make long-term decisions even if there are no profits in short-terms. Listed companies increase corporate social responsibility matters in order to survive in long-term competitions. We assume that the influence of csr activities is lasting to next operating period and affect current analyst forecast.

H2: Ceteris paribus, csr disclosure quality in previous year decreases current analyst forecast error.

Score $_{i, t}$ and score $_{i, t-1}$ are the contemporaneous and previous year's csr disclosure quality index for firm i. We include the lagged effect of csr to capture any time-series effect of csr disclosure on analyst forecast properties.

2.2.2 csr disclosure quality and analyst forecast optimism

In prior studies, it has been proved that analysts are optimistic about earnings forecast (e.g., Fried and Givoly, 1982; Dowen, 1989; Butler and Lang, 1991; Calderon, 1993; Chopra, 1998). When analysts' predictions on earnings per share exceed actual earnings per share, analyst forecast optimism will exist (Calderon, 1993).

Hong and Kubik (2003) find job separations were less sensitive to accuracy and more sensitive to optimism covering approximately 600 brokerage houses for the period 1983 to 2000 . Brokerage houses apparently reward optimistic analysts who promote stock sales.

Ioannou and Serafeim (2015) find experienced analysts with more firm-specific csr reporting practices and analysts at higher-status brokerage houses shift the relation between csr ratings and investment recommendation from pessimism to optimism with high csr ratings. Csr strengths push more strongly towards "buy" recommendations for these analysts with a better understanding of csr strategies compared to other analysts.

In spite of a large body of literature has rejected rational expectations in relation to analyst forecasts (Lee et al., 2008) there are studies support the bounded rationality assumption of financial analysts. Economists who include bounds on rationality in their models have excellent success in describing economic behavior (Conlisk, 1996). Lee et al. (2008) start with the bounded rationality assumption and their analysis support the conclusion that the observed bounded rational behavior of analysts in forecasting growth.

Although in the early year analysts make optimistic earnings forecasts with low issuing cost to maintain a good relationship with management (Wong and Zhang, 2014), analysts revise their forecasts bias downward gradually as arriving more objective information throughout the year. As a result, based on the bounded rationality and further extension of information disclosures, we assume analysts reduce their optimism in the forecast process step by step. As hinted above, we predict the hypotheses formally based on contemporaneous csr disclosure quality and previous year csr disclosure quality.

H3: Ceteris paribus, contemporaneous csr disclosure quality decreases current analyst forecast optimism.

H4: Ceteris paribus, csr disclosure quality in previous year decreases current analyst forecast optimism.

\section{Sample, variable and research design}

\section{1 sample}

Firm-specific csr information varies widely in terms of content, format, and assessment in shanghai stock exchange and shenzhen stock exchange. Csr information disclosure is assessed annually and the results are divided into four grades: excellent, good, pass and fail in shenzhen stock exchange. Shanghai stock exchange publishes sse social responsibility index, referred to as responsibility index with the code 000048 from August 2009. It is impossible that the firm-specific csr information can be cited directly. Since csr disclosure information has been explored more 
differently in the two stock exchanges, we adopt the disclosure information provided by the third leading csr rating agency_rankins csr ratings (rks). Listed companies in shanghai stock exchange and shenzhen stock exchange are all included in rks database. The same basic criteria in evaluation process are used for firm-specific csr information for different stock exchanges. Rks database is the most often cited database used in csr research in China now.

We obtain analyst forecast data from China stock market accounting research (csmar) database, financial data from csmar and wind database. We include published csr reports listed firms from 2012 to 2015; financial variables and analyst forecast properties from 2013 to 2015. One year earlier csr disclosures are used for the lagged effect on current analyst forecast. Finance and insurance firms are excluded on account of their unique accounting standards. We exclude the firms under st (special treatment) or *st (risk admonition) status; furthermore, industries with low proportions summarizing proportions $0.58 \%$, which are $\mathrm{h}, \mathrm{m}$ and $\mathrm{q}$ are excluded. We winsorize the data to the upper and lower $1 \%$ percentiles for each variable used in the regression to ensure that there are no extreme values. Table 1 reports the sample processing and table 2 shows the industry distribution of the sample. Listed companies published csr reports in China increase gradually from table1. Table 2 describes that listed companies in manufacturing industry publish csr reports more than other industries. software.

Data processing and analyses are carried out by using excel2010 and stata 14.0 statistical Table1

\begin{tabular}{|c|c|c|c|c|c|}
\hline sample & 2012 & 2013 & 2014 & 2015 & total sample \\
\hline $\begin{array}{l}\text { listed companies } \\
\text { published } c s r \text { reports }\end{array}$ & 562 & 644 & 681 & 708 & 2595 \\
\hline $\begin{array}{l}\text { minus: } \\
\text { firms with missing analyst } \\
\text { forecasts }\end{array}$ & 0 & 142 & 145 & 173 & 460 \\
\hline finance and insurance firms & 39 & 40 & 44 & 46 & 169 \\
\hline $\begin{array}{l}\text { firms under st } \quad \text { (special } \\
\text { treatment) or } * \text { st (risk } \\
\text { admonition) status }\end{array}$ & 0 & 0 & 2 & 2 & 4 \\
\hline $\begin{array}{l}\text { firms with missing financial } \\
\text { data }\end{array}$ & 0 & 6 & 25 & 10 & 41 \\
\hline $\begin{array}{l}\text { industry with small sample } \\
\text { size }\end{array}$ & 3 & 3 & 4 & 5 & 15 \\
\hline $\begin{array}{l}\text { Total sample (previous year } \\
\text { csr) }\end{array}$ & 520 & 453 & 461 & 472 & 1906 \\
\hline $\begin{array}{l}\text { Total sample } \\
\text { (contemporaneous } c s r \text { ) }\end{array}$ & & 453 & 461 & 472 & 1386 \\
\hline $\begin{array}{l}\text { total sample (previous year } \\
c s r \text { ) }\end{array}$ & 520 & 453 & 461 & 472 & 1906 \\
\hline $\begin{array}{l}\text { minus: missing lagged } \\
\text { values }\end{array}$ & & & & & 781 \\
\hline $\begin{array}{l}\text { Final total sample (previous } \\
\text { year } c s r \text { ) }\end{array}$ & & & & & 1125 \\
\hline
\end{tabular}


Table 2

\begin{tabular}{ccccccc}
\hline industry & 2012 & 2013 & 2014 & 2015 & total & percentage $(\%)$ \\
\hline a & 7 & 8 & 9 & 10 & 34 & 1.31 \\
b & 28 & 30 & 32 & 32 & 122 & 4.70 \\
c & 294 & 356 & 370 & 380 & 1399 & 53.91 \\
d & 34 & 35 & 38 & 38 & 145 & 5.59 \\
e & 17 & 21 & 23 & 26 & 87 & 3.35 \\
f & 28 & 31 & 34 & 35 & 128 & 4.93 \\
g & 36 & 37 & 37 & 36 & 146 & 5.63 \\
h & 1 & 1 & 1 & 1 & 4 & 0.15 \\
i & 20 & 26 & 28 & 30 & 104 & 4.01 \\
j & 39 & 40 & 44 & 46 & 169 & 6.51 \\
k & 38 & 40 & 41 & 43 & 162 & 6.24 \\
I & 5 & 5 & 6 & 7 & 23 & 0.89 \\
m & 0 & 0 & 0 & 1 & 1 & 0.04 \\
n & 4 & 5 & 4 & 6 & 19 & 0.73 \\
q & 2 & 2 & 3 & 3 & 10 & 0.39 \\
r & 5 & 3 & 7 & 10 & 25 & 0.96 \\
s & 4 & 4 & 4 & 5 & 17 & 0.66 \\
\hline total & 562 & 644 & 681 & 708 & 2595 & 100 \\
\hline
\end{tabular}

a- agriculture (forestry, farming, animal husbandry, fishery); b- mining and quarrying; cmanufacturing; d- utilities(electric power, heat power, gas and tap water); e-construction; f-wholesale and retail trades; g-transport, storage and postal services; h-accommodation and catering; i-information transfer, software and information technology services; j-finance(monetary and financial services, capital market service, insurance and other financial services); k-real estate; l-leasing and commercial services; $\mathrm{m}$ - scientific research and polytechnic services; n-administration of water, environment and public facilities; o- resident 、 repair and other services; q- health care and social work; r- culture, sports and entertainment; s-public administration, social insurance and social organizations.

\section{2 variable}

3.2.1 dependent variables

(1) analyst forecast error

Prior studies find that the accuracy of analyst earnings forecasts is response to management earnings forecasts (Waymire, 1986; Jennings, 1987; Baginski and Hassell, 1990; Williams, 1996). Indeed, management earnings forecasts have advantages of being disclosure events (Lang and Lundholm, 1996), but which are difficult to quantify. As an alternative to management earnings forecasts, more comprehensive measures have been putted into practice (Kross et al., 1990; Lang and Lundholm, 1996; Barron et al., 1999; Dhaliwal et al., 2012). Consistent with Lang and Lundholm (1996), analyst forecast accuracy is as follows:

$$
\text { forecast accuracy }=-\left(\left|\operatorname{eps}_{\mathrm{t}}-\mathrm{af}_{\mathrm{t}}\right|\right) / \mathrm{p}_{\mathrm{t}}
$$

$e p s_{t}$ is earnings per share in period $\mathrm{t}$; $a f_{t}$ is the median analyst forecast of earning per share in period $\mathrm{t}$; $p_{t}$ is price per share in period t. The shortcoming of this model is the application of median analyst forecast, which smooths the forecast differentiations of distinct analysts.

Dhaliwal et al. (2012) use analyst forecast error as an inverse measure of forecast accuracy. His model overcomes the weakness of Lang and Lundholm's model and includes the forecast results of each analyst, reflecting differences in analyst forecasts rather than using the median forecast.

$$
\operatorname{error}(y)_{i, t}=\frac{1}{n} \sum_{j=1}^{n}\left|f_{i, t, j}^{y}-e p s_{i, t}^{y}\right| / p_{i, t}
$$

$E p s_{i, t}^{y}$ is the actual earnings per share for firm i, year t. $F c_{i, t, j}^{y}$ is the analyst j's forecast earnings per 
share for firm i, year t. $P_{i, t}$ is the stock price at the beginning of the year $\mathrm{t}$. Indicator $\mathrm{Y}$ takes three values, $0,1,2$, to denote whether the target earnings and the forecast are for the current year, one year ahead, or two years ahead. According to De Bondt and Thalery (1990)'s conclusion that analyst forecast error gets larger as the forecast horizon increases, Dhaliwal et al. (2012) limit the forecast horizon to a maximum of two years. Barron et al. (1999) define forecast error as the standard deviation in individual analyst's earnings forecast around actual earnings divided by the absolute actual earnings.

Consistent with Dhaliwal et al. (2012) and Barron et al. (1999), Lang and Lundholm (1996), we construct analyst forecast error as follows:

$$
\operatorname{error}_{i, t}=\frac{\frac{1}{\mathrm{n}} \sum_{\mathrm{j}=1}^{\mathrm{n}}\left|\mathrm{feps}_{\mathrm{i}, \mathrm{t}, \mathrm{j}}-\mathrm{aeps}_{\mathrm{i}, \mathrm{t}}\right|}{\left|\mathrm{aeps}_{\mathrm{i}, \mathrm{t}}\right|}
$$

$\operatorname{Aeps}_{i, t}$ is the actual earnings per share for firm i, year t. Feps $s_{i, t, j}$ is the analyst j's forecast earnings per share for firm i, year t. $\frac{1}{n} \sum_{j=1}^{n}\left|f e p s_{i, t, j}-a e p s_{i, t}\right|$ is the average absolute deviation of all analysts. Consistent to Dhaliwal et al. (2012), the difference is the denominator, we use $\mid$ aeps $_{i, t} \mid$ instead of $p_{i, t}$. According to efficient market hypothesis (Fama, 1970), there are three categories of efficient market model: strong form; semi-strong form and weak form. At present, the capital market in China is not as efficient as in U.S market. $P_{i, t}$ is difficult to measure sophisticated firm-specific information in China completely.

Now we define available forecast earnings per share. Previous research (e.g., O'Brien, 1988; Brown and Kim, 1991) has documented that timely composites of analysts' forecasts are superior to the mean forecast in terms of predictive ability (Brown and Kim, 1991). O' Brien (1988) examines three composites of available forecasts: the mean, the median, and the most current forecast and considers more current forecasts may be more accurate because most current forecast is a reasonable aggregation of the information. A "staleness" problem arises because forecasts are made in prior months and are not yet updated but more timely forecasts are likely to better capture market expectations throughout the year (Brown and Kim, 1991). Crichfield et al. (1978) examine several aspects of analyst forecast quality and indicate that analysts' forecasts become more accurate as the reporting date is approached and there has no significant systematic bias to the predictions of changes in earnings per share. Therefore, the selected forecast earnings per share we rely on is the analyst j' last time forecast approaching the financial reports announcements.

(2) analyst forecast optimism

Butler and Lang (1991) examine the individual forecast accuracy and find at least 69\% of individual analysts' average annual forecasts fell above average annual actual earnings. Analysts appear to use their annual earnings forecasts to develop their recommendations (Bradshaw, 2004). Consequently, Kadous et al. (2006) find to reduce analyst forecast optimism resulting in higher returns for investors who rely on analysts' recommendations.

Duru and Reeb (2002) investigate the association between corporate international diversification and analyst forecast accuracy and optimism. The results suggest that greater corporate international diversification is associated with less accurate and more optimistic forecasts. They measure optimism defined as the difference between the consensus earnings forecast and the actual earnings, scaled by the stock price.

$$
\text { optimism }=\frac{\text { feps }_{\mathrm{t}}^{\mathrm{t}-1}-\mathrm{aeps}_{\mathrm{t}}}{\text { price }_{\mathrm{t}-1}}
$$

Lang et al. (2003), Herrmann et al. (2008) and Zhang et al. (2010) measure analyst forecast optimism consistent with Duru and Reeb (2002). Based on prior studies, analyst forecast optimism is expressed as follows

$$
\operatorname{optimism}_{i, t}=\frac{\text { feps }_{\mathrm{i}, \mathrm{t}, \mathrm{j}}-\mathrm{afeps}_{\mathrm{i}, \mathrm{t}, \mathrm{j}}}{\mathrm{p}_{\mathrm{i}, \mathrm{t}}}
$$

$\operatorname{Aeps}_{i, t}$ is the actual earnings per share for firm i, year t. $F e p s_{i, t, j}$ is the analyst j's forecast earnings per share for firm $i$, year $t$. 


\subsection{2 independent variable}

(1) csr disclosure rating score

Corporate social responsibility (csr) is a multidimensional concept (Nicolosia et al., 2014). The evaluation system of rks (mct 2012_1.2i) is based on the international standards of social responsibility (iso26000) and re-modified in consideration of the local situation in China. The significant difference between the new (mct 2012_1.2i) and the old (mct 2010_1.1) version is to add industry index to proxy the industry differentiation from the year 2012. Based on mct 2012_1.2i criteria, csr scores are assessed including macrocosm, content, technique and industry four dimensions. Based on a structured evaluation method, total csr disclosure score is 100 . The proportion of the four dimensions is as follows in Fig. 1.

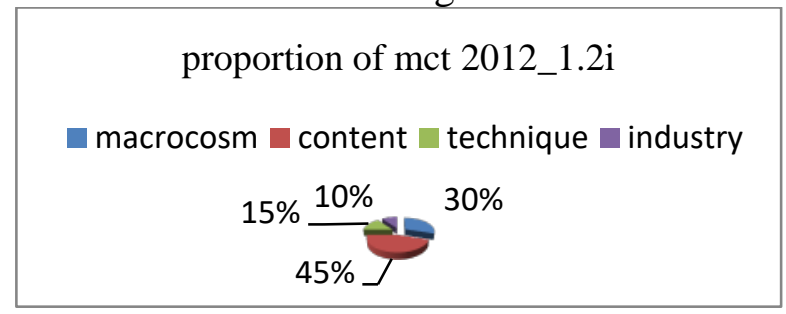

Fig.1 proportion of mct 2012_1.2i

Disclosure policy and characteristics of firms' information environments are notoriously difficult to measure (Lang, 1999). Lang and Lundholm (1996), Welker (1995) use disclosure ratings provided by the association for investment management and research as a proxy for information disclosure. Disclosure ratings have the advantage of being a more comprehensive measure. Csr scores and firm disclosures are much stronger for the more informal and flexible aspects of firm (Gelb and Strawser, 2001). We use data of rating scores from rks database as a comprehensive proxy for a firm's csr disclosure quality. As a result, csr disclosure rating score in rks database provides objective, summary data indicating the presence or absence of distinct mcti criteria and reflecting the voluntary disclosure quality or mandatory disclosure quality for listed firms on an annual basis.

3.2.3 control variables

(1) analyst following

Lang and Lundholm (1996) note that, most of the empirical research on the determinants of analyst following focuses on firm characteristics other than disclosure policy. For example, the number of analysts following is related to firm size (Bhushan, 1989; Brennan and Hughes,1991); return volatility (Bhushan,1989; O'Brien and Bhushan,1990; Brennan and Hughes,1991); stock splits and stock performance (Brennan and Hughes, 1991; Healy and Palepu, 2001); institutional ownership (Bhushan, 1989; Healy and Palepu, 2001). With the significant changes in economic environment, information disclosure policies are received adequate attention. Empirical evidences find that the efficient way to get the financial analysts' attention is to voluntarily provide much more information. Benefits and costs are traded off for analysts through precise disclosures and informative earnings (Healy et al., 1999; McWilliams and Siegel, 2001). Socially responsible and high-quality companies with more forthcoming information disclosure practices have a larger analyst following. Analysts who provide better earnings forecasts will play a more active monitoring role (Yu, 2009). Empirical surveys have shown that there has a significantly positive effect of analyst following on analyst forecast accuracy, negative effect of analyst following on forecast error and dispersion (Lang and Lundholm, 1996; Botosan, 1997; Hope, 2003; Bai, 2009; Jo and Harjoto, 2014).

(2) firm size

Firm size plays an import role in formativeness of stock price and price-based models of earnings prediction (Wild and Kwon, 1994). Surveys have shown a positive trend of the effect of firm size on csr information disclosure practices of Australian companies (Trotman and Bradley, 1981). Holder-Webb et al. (2009) extend the csr disclosure practices with a size- and industry-stratified sample of 50 publicly-traded U.S. firms during 2004. Consistent with previously 
reported studies, firm size has been shown to have a significantly positive effect on analyst forecast accuracy and, negative effect on forecast error and dispersion (Lang and Lundholm, 1996; Barron et. al., 1999).

\section{(3) csr disclosure type}

Holder-Webb et al. (2009) find companies voluntarily disclose such information including more segment details, supplemental nonfinancial data, and additional forward-looking information are likely to receive private benefits from a lower cost of capital. Using data of companies across three continental European countries, Vanstraelen et al. (2003) show that larger companies and internationally oriented companies provide voluntary higher levels of forward looking nonfinancial disclosures which are associated with lower error and higher accuracy in financial analysts' earnings forecasts. Firms extended voluntary disclosures are accompanied by improved stock performance, as well as institutional ownership, analyst following, stock liquidity (Healy et al., 1999). Managers make voluntary disclosures to reduce information risk (Graham and Harvey, 2005). Therefore, voluntary nonfinancial disclosures play a crucial role in capital markets (Lang and Loundholm 2000).

(4) leverage

Investment decisions are more sensitive to firm liquidity in financially constrained firms than less constrained firms (Cleary, 1999). Lang et al. (1996) discover leverage is negatively related to future growth for firms whose growth opportunities are not recognized by the capital markets and whose growth opportunities are not sufficiently valuable to overcome the effects of debt overhang. Higher leverage proportion, easier falling into financial distress. Executives set the information barriers between creditors and firms in order to prevent the violation of debt covenants, causing deeper information opacity. It is difficult for analysts to collect and analyze folded information, which affects their forecast accuracy and optimism.

(5) institutional ownership

Institutions influence a firm's portfolios (El-Gazzar, 1998) and the pricing of accruals (Collins et al., 2003). Institutional ownership in a stock increases the demand for informative analyst research (Frankel et al., 2006). Examining a sample of analyst recommendations available in the i/b/e/s database over the 1994-2000 periods, Ljungqvist et al. (2007) find more accurate sell-side earnings forecasts and more timely re-ratings when share price falls are associated with the presence of institutional investors because analysts are dependent on institutional investors for performance ratings and trading commissions. Analysts prefer to issue optimistic forecasts to please institutional investors for their career improvement and trading commissions.

(6) duality

Klein (2002) examines whether audit committee and board characteristics are related to earnings management. The results suggest that boards structured to be more independent of the ceo are more effective in monitoring the corporate financial accounting process. Executives and directors are the most informed party with respect to the firm's operations, risks and opportunities; however, insider trading activities decrease firm-specific information efficiency (Piotroski and Roulstone, 2004). Rechner and Dalton (1991) examine differential financial performance regarding independent or duality board leadership structure for 141 corporations over 6 years. Results indicate firms opting for independent leadership consistently outperform ceo duality board leadership structure. Duality board structure makes against information fully disclosures, increasing the information asymmetry. All of these make it is harder for analyst forecasts.

(7) auditing assurance

Darnall et al. (2009) show environmental audits lead to superior business performance as a result of greater opportunities for improved operational efficiency and effectiveness. Simnett et al. (2009) argue that companies seek to enhance their nonfinancial reports credibility and build corporate reputation using assured sustainability reports. Rhianon et al. (2010) discover that stakeholders are being increasing included in the social and environmental report assurance. Assured csr reports enhance credibility, reliability and information transparency for stakeholders; therefore, assured csr reports improve accuracy of analyst forecasts. 
Table3 presents all the variables.

Table 3

\begin{tabular}{|c|c|c|}
\hline variables & variable code & variable description \\
\hline \multicolumn{3}{|l|}{ dependent variables: } \\
\hline forecast error & error & $\operatorname{error}_{i, t}=\frac{\frac{1}{n} \sum_{j=1}^{n} \mid \text { feps }_{i, t, j}-\text { aeps }_{i, t} \mid}{\mid \text { aeps }_{i, t} \mid}$ \\
\hline Forecast optimism & optimism & optimism $_{i, t}=\frac{\text { feps }_{i, t, j}-\text { afeps }_{i, t, j}}{p_{j}}$ \\
\hline \multicolumn{3}{|l|}{ independent variables: } \\
\hline \multirow[t]{2}{*}{ csr disclosure quality } & score $_{t}$ & contemporaneous csr disclosure quality \\
\hline & score $_{t-1}$ & csr disclosure quality in previous year \\
\hline \multicolumn{3}{|l|}{ control variables: } \\
\hline analyst following & anano & $\begin{array}{l}\text { the nature logarithm of the number of } \\
\text { analysts following plus one through the } \\
\text { year, } \ln (\text { following }+1 \text { ) }\end{array}$ \\
\hline firm size & size & $\begin{array}{l}\text { the nature logarithm of the end of the } \\
\text { previous year's assets. }\end{array}$ \\
\hline csr disclosure type & open & $\begin{array}{l}\text { open takes a value of } 1 \text { if the listed } \\
\text { companies disclose voluntary csr reports } \\
\text { and } 0 \text { otherwise. }\end{array}$ \\
\hline financial leverage & lev & financial leverage \\
\hline institutional ownership & insshare & institutional investor shareholding \\
\hline duality & duality & $\begin{array}{l}\text { duality takes a value of } 1 \text { if the chairman of } \\
\text { the board and ceo are the same person, } 0 \\
\text { otherwise. }\end{array}$ \\
\hline auditing assurance & assurance & $\begin{array}{l}\text { assurance equals } 1 \text { if the } c s r \text { reports are } \\
\text { assured by a third party and } 0 \text { otherwise. }\end{array}$ \\
\hline
\end{tabular}

\section{3 research design}

To test hypothesis H1and H2, we estimate the following baseline models (3) (4) to examine the effect of csr disclosure quality on analyst forecast errors.

$$
\text { error }_{i, t}=\alpha_{0}+\alpha_{1} \text { score }_{i, t}+\alpha_{2-8} \text { control variables }+\varepsilon_{i, t}
$$

Model (3) is constructed to test H1, independent variable $s_{c o r} e_{i, t}$, presents contemporaneous csr disclosure quality. In the model, $\alpha_{1}$ is the coefficient of contemporaneous csr disclosure quality. If the coefficient is negative, it shows contemporaneous csr disclosure quality decreases analyst forecast error.

$$
\text { error }_{i, t}=\alpha_{0}+\alpha_{1} \text { score }_{i, t-1}+\alpha_{2-8} \text { control variables }+\varepsilon_{i, t}
$$

Model (4) is constructed to test H2, independent variable $s_{c o r e} e_{i, t-1}$, presents $c s r$ disclosure quality in previous year. If the coefficient $\alpha_{1}$ is negative, it shows csr disclosure quality in previous year decreases current analyst forecast error.

To test $\mathrm{H} 3$ and H4, we construct model (5) (6)

$$
\begin{aligned}
& \text { optimism }_{i, t}=\alpha_{0}+\alpha_{1} \text { score }_{i, t}+\alpha_{2-8} \text { control variables }+\varepsilon_{i, t} \\
& \text { optimism }_{i, t}=\alpha_{0}+\alpha_{1} \text { score }_{i, t-1}+\alpha_{2-8} \text { control variables }+\varepsilon_{i, t}
\end{aligned}
$$

To test $\mathrm{H} 3$ and $\mathrm{H} 4$, the relationship between $c s r$ disclosure quality and analyst forecast optimism, we construct model (5) and model (6). If the coefficients of $s_{c o r e} e_{i, t}$ and $s_{c o r e} e_{i, t-1}$ are both significantly negative, H3and $\mathrm{H} 4$ will be supported.

\section{Empirical results}

\section{1 descriptive statistics}

Table 4 displays the descriptive statistics for each variable. The average forecast error is 0.406 , analysts are supposed to improve forecast accuracy. Mean optimism is 0.01 , indicating the degree of analyst forecast optimism is not high currently. The average csr score is 39.363, the minimum is 15.115 , the maximum value is 87.948 , indicating that there is a huge difference between social behaviors in listed companies in China. Average proportion of voluntary csr disclosures is 37.3\%, approximate 2/3 listed companies prove mandatory csr disclosures. The logarithm average number 
of analysts following for each firm is 2.215, the minimum is 0.693 and the maximum is 3.989 , indicating that analysts are not equally concerned about the listed companies. The mean proportions of institutional investors shareholding and leverage in capital market is approximate $50 \%$, the mean proportions are high. Note that the average assurance is only 0.019, which indicates the csr reports assured by a third party is really low at present in listed companies in China capital markets.

Table 4

\begin{tabular}{lcccccr}
\hline variable & mean & sd & min & median & max & $\mathrm{N}$ \\
\hline error & 0.406 & 0.430 & 0 & 0.225 & 2 & 1386 \\
optimism & 0.010 & 0.028 & -0.113 & 0.005 & 0.344 & 1386 \\
score & 39.363 & 12.042 & 15.115 & 36.361 & 87.948 & 1906 \\
lscore & 39.042 & 12.330 & 15.115 & 35.631 & 87.948 & 1125 \\
anano & 2.215 & 0.862 & 0.693 & 2.303 & 3.989 & 1386 \\
size & 23.242 & 1.451 & 19.629 & 23.107 & 28.509 & 1386 \\
open & 0.373 & 0.484 & 0 & 0 & 1 & 1906 \\
lev & 0.487 & 0.205 & 0.008 & 0.493 & 1.345 & 1386 \\
insshare & 0.524 & 0.224 & 0.001 & 0.552 & 1.009 & 1386 \\
duality & 0.166 & 0.372 & 0 & 0 & 1 & 1386 \\
assurance & 0.019 & 0.138 & 0 & 0 & 1 & 1906 \\
\hline
\end{tabular}

\section{2 correlation analysis}

Table 5 shows the Pearson correlation matrix of the variables used in the following empirical tests. Csr disclosure score and one year lagged disclosure score are negatively correlated with analyst forecast error and optimism, which are consistent with hypotheses. Analyst following significantly improves analyst forecast accuracy and mitigates their forecast optimism. There is a negative correlation between firm size and analyst forecast error but large scale of firms attracts more analyst following then leads to more optimistic forecasts. The proxy for firm-specific financial leverage is significantly positively correlated with analyst forecast error, optimism and csr disclosure scores. Institutional ownership increases accuracy of analyst forecast and more optimistic forecasts for pleasing institutional investors. Duality exacerbates analyst forecast error and is not conducive to csr information disclosure. Auditing assurance decreases the forecast error and optimism, but the effect is not significant. All the matrix coefficients are less than 0.5 , which means that we are no need for caring about multicollinearity.

Table 5 Pearson correlation matrix

\begin{tabular}{|c|c|c|c|c|c|c|c|c|c|c|c|}
\hline & error & optimism & score & lscore & anano & size & open & lev & insshare & duality & yassurance \\
\hline error & 1 & & & & & & & & & & \\
\hline optimism & $0.401 * * *$ & 1 & & & & & & & & & \\
\hline score & $-0.114 * * *$ & -0.033 & 1 & & & & & & & & \\
\hline lscore & $-0.116 * * *$ & $-0.052 *$ & $0.933 * * *$ & 1 & & & & & & & \\
\hline anano & $-0.171 * * *$ & $-0.084 * * *$ & $0.191^{* * * *}$ & $0.172 * * *$ & 1 & & & & & & \\
\hline size & $-0.118 * * *$ & $0.053 * *$ & $0.428 * * *$ & $0.421 * * *$ & $0.252 * * *$ & 1 & & & & & \\
\hline open & $0.061^{* *}$ & $0.047 *$ & $-0.133 * * *$ & $-0.130 * * *$ & $-0.121 * * *$ & $-0.479 * * *$ & 1 & & & & \\
\hline lev & $0.071 * * *$ & $0.235 * * *$ & $0.152 * * *$ & $0.138 * * *$ & $-0.080 * * *$ & $0.569 * * *$ & $-0.222 * * *$ & 1 & & & \\
\hline insshare & $-0.160 * * *$ & 0.015 & $0.253^{* * *}$ & $0.244^{* * *}$ & $0.170^{* * *}$ & $0.427 * * *$ & $-0.270 * * *$ & $0.213^{* * *}$ & 1 & & \\
\hline duality & 0.017 & 0.014 & $-0.070 * * *$ & -0.039 & 0.033 & $-0.164 * * *$ & $0.126^{* * *}$ & $-0.120 * * *$ & $-0.162 * * *$ & 1 & \\
\hline assurance & -0.030 & -0.022 & $0.377^{* * *} *$ & $0.458 * * *$ & $0.087 * * *$ & $0.211^{* * *}$ & $-0.053 * *$ & 0.046* & $0.126^{* * *}$ & -0.038 & 1 \\
\hline
\end{tabular}

\section{3 empirical analysis}

We are supposed to choose superior methodology among pooled ols, fixed effect and random effect according to unbalanced short panel data (lagged csr) and balanced short panel data (contemporaneous csr). There are three steps to choose superior methodology. Firstly, F-test is used for choice of pooled ols and fixed effect. The criteria are the $f$ value and its corresponding p-value. If f's corresponding p-value is less than 0.05, fixed effect model is superior. Secondly, bp-lm test is used to select models between pooled ols and random effect. Finally, hausman test is put into practice to reject or accept random effect comparing with fixed effect. The criteria are based on 
p-value of hausman test, if p-value is less than 5\%, random effect will be rejected; otherwise, random effect will be accepted. Statistical consequences in table 6 and table 7 are the most superior results carried out f-test, bp-lm test and hausman test. Inconsistent with prior studies, random effect is superior to fixed effect and pooled ols in our models.

Note that adopting cluster robust standard error to estimate short panel data, such defects as heteroscedasticity can be solved. All robust standard errors are adjusted for clusters in stocks in our statistical analyses.

4.3.1 csr disclosure quality and forecast error

We check the relation between csr disclosure quality and forecast error to test $\mathrm{H} 1$ and $\mathrm{H} 2$ in table 6 .

Table 6

\begin{tabular}{|c|c|c|}
\hline variables & $\begin{array}{c}\text { model(3) } \\
\text { error }\end{array}$ & $\begin{array}{c}\text { model(4) } \\
\text { error } \\
\end{array}$ \\
\hline constant & (5.52) & $\begin{array}{l}1.319 * * * \\
(4.31)\end{array}$ \\
\hline score & $\begin{array}{l}-0.002 * \\
(-1.87)\end{array}$ & \\
\hline lscore & & $\begin{array}{c}-0.003 * * \\
(-2.15)\end{array}$ \\
\hline anano & $\begin{array}{c}-0.053 * * * \\
(-3.27)\end{array}$ & $\begin{array}{c}-0.039 * * \\
(-2.25)\end{array}$ \\
\hline size & $\begin{array}{c}-0.045^{* * *} \\
(-3.09)\end{array}$ & $\begin{array}{c}-0.034^{* *} \\
(-2.27)\end{array}$ \\
\hline open & $(-1.00)$ & $\begin{array}{l}-0.019 \\
(-0.58)\end{array}$ \\
\hline lev & $\begin{array}{c}0.324 * * * \\
(3.78)\end{array}$ & $\begin{array}{c}0.336^{* * *} \\
(3.92)\end{array}$ \\
\hline insshare & $\begin{array}{c}-0.236 * * * \\
(-3.96)\end{array}$ & $\begin{array}{c}-0.241^{* * *} \\
(-3.82)\end{array}$ \\
\hline duality & $\begin{array}{l}-0.014 \\
(-0.43)\end{array}$ & $\begin{array}{l}0.011 \\
(0.30)\end{array}$ \\
\hline assurance & $\begin{array}{c}0.126^{*} \\
(1.85)\end{array}$ & $\begin{array}{l}0.108^{*} \\
(1.77)\end{array}$ \\
\hline year & control & control \\
\hline within r2 & 0.0234 & 0.0303 \\
\hline between r2 & 0.1089 & 0.0896 \\
\hline overall r2 & 0.0759 & 0.0648 \\
\hline number of stock & 619 & 497 \\
\hline observations & 1,386 & 1125 \\
\hline $\mathrm{p}$ & 0 & 0 \\
\hline
\end{tabular}

Robust z-statistics in parentheses, $\mathrm{p}<0.01,{ }^{*} \mathrm{p}<0.05,{ }^{*} \mathrm{p}<0.1$

The results show that, the coefficient of score is $-0.002(\mathrm{t}=-1.87)$, which is significant at the level of $10 \%$. The result shows that contemporaneous csr disclosure quality significantly decreases current analyst forecast error, $\mathrm{H} 1$ is supported. The coefficient of lagged score is $-0.003(\mathrm{t}=-2.15)$, which is significant at the level of $5 \%$. Csr disclosure quality in previous year significantly decreases current analyst forecast error, as a result $\mathrm{H} 2$ is supported. The coefficients of $s c o r e_{i, t}$ and score $_{i, t-1}$ are both negatively and significantly. The implementation of csr activities has a time-series effect, analysts predict earnings considering not only current csr disclosure quality but also previous year's score. Results show that the effect of csr disclosure quality in previous year is 
more significant than contemporaneous csr disclosure quality on decreasing analyst forecast error.

The effect of controlling variables on analyst forecast error is presented as follows. Three variables, analyst following, firm size and institution ownership, significantly decrease analyst forecast error no matter the current year or previous year. Voluntary csr disclosure is negative with forecast error, which is consistent with Vanstraelen et al. (2003). We find the higher the leverage, the lower the forecast accuracy. It is surprise to find the coefficient of auditing assurance is positively related to error, which is likely because that the quality of the third auditing assurance party is varied and there are no unified criteria for csr reports assurance. Guaranteed auditing quality is low.

4.3.2 csr disclosure quality and forecast optimism

We check the relation between $c s r$ disclosure quality and forecast optimism to test $\mathrm{H} 3$ and $\mathrm{H} 4$ in table 7.

Table 7

\begin{tabular}{|c|c|c|}
\hline variables & $\begin{array}{l}\text { model(5) } \\
\text { optimism }\end{array}$ & $\begin{array}{l}\text { model(6) } \\
\text { optimism }\end{array}$ \\
\hline constant & $\begin{array}{l}0.009 \\
(0.55)\end{array}$ & $\begin{array}{l}0.025 \\
(1.51)\end{array}$ \\
\hline score & $\begin{array}{l}-0.000 \\
(-1.39)\end{array}$ & \\
\hline lscore & & $\begin{array}{r}-0.000^{*} \\
(-1.71)\end{array}$ \\
\hline anano & $\begin{array}{l}-0.001 \\
(-1.18)\end{array}$ & $\begin{array}{l}-0.000 \\
(-0.03)\end{array}$ \\
\hline size & $\begin{array}{l}-0.000 \\
(-0.61)\end{array}$ & $\begin{array}{l}-0.001 \\
(-1.36)\end{array}$ \\
\hline open & $\begin{array}{l}0.004 * * \\
(2.15)\end{array}$ & $\begin{array}{l}0.001 \\
(0.49)\end{array}$ \\
\hline lev & $\begin{array}{c}0.032 * * * \\
(6.27)\end{array}$ & $\begin{array}{c}0.031 * * * \\
(5.35)\end{array}$ \\
\hline insshare & $\begin{array}{l}0.001 \\
(0.30)\end{array}$ & $\begin{array}{l}-0.001 \\
(-0.42)\end{array}$ \\
\hline duality & $\begin{array}{l}0.001 \\
(0.72)\end{array}$ & $\begin{array}{l}-0.000 \\
(-0.12)\end{array}$ \\
\hline assurance & $\begin{array}{l}0.001 \\
(0.45)\end{array}$ & $\begin{array}{l}0.004 \\
(1.62)\end{array}$ \\
\hline year & control & control \\
\hline within r2 & 0.0115 & 0.0125 \\
\hline between r2 & 0.1061 & 0.0982 \\
\hline overall r2 & 0.0677 & 0.0550 \\
\hline number of stock & 619 & 497 \\
\hline observations & 1,386 & 1125 \\
\hline $\mathrm{p}$ & $4.86 e-07$ & 7.41e-05 \\
\hline
\end{tabular}

Robust z-statistics in parentheses, $\mathrm{p}<0.01$, ** $\mathrm{p}<0.05,{ }^{*} \mathrm{p}<0.1$

The coefficient of score is $-0.000(\mathrm{t}=-1.39)$, which is not significant in different levels. The result shows that contemporaneous csr disclosure quality decreases current analyst forecast optimism but it is not significant, H3 is not supported. The coefficient of lagged score is $-0.000(\mathrm{t}=$ -1.71 ), which is significant at the level of $10 \%$. Csr disclosure quality in previous year significantly decreases current analyst forecast optimism, as a result $\mathrm{H} 4$ is supported. The coefficients of score $_{i, t}$ and score $_{i, t-1}$ are both negative and the effect of $c s r$ disclosure quality in previous year 
is more significant than contemporaneous csr disclosure quality on decreasing analyst forecast optimism.

Two variables, analyst following and firm size, decrease analyst forecast optimism in the current year and in previous year. Voluntary csr disclosures are positive with forecast optimism. Firms provide voluntary csr reports to improve information transparency and attract more analysts following.

\section{Robustness test}

As discussed in empirical analysis, random effect is superior to fixed effect and pooled ols in our models carried out f-test, bp-lm test and hausman test. Random effect model is estimated by generalized least squares (gls). There are various estimation methods for feasible generalized least squares (fgls) including the maximum likelihood method and simulation. We use maximum likelihood estimator (mle) method to check robustness of our results. We discover that the results do not change based on mle robustness test. We report the results in table 8 and table 9 .

Table 8

\begin{tabular}{|c|c|c|}
\hline variables & $\begin{array}{c}\text { model(3) } \\
\text { error } \\
\end{array}$ & $\begin{array}{c}\text { model(4) } \\
\text { error } \\
\end{array}$ \\
\hline constant & $\begin{array}{c}1.599 * * * \\
(5.44)\end{array}$ & $\begin{array}{c}1.295^{* * *} \\
(4.20)\end{array}$ \\
\hline score & $\begin{array}{l}-0.002 * \\
(-1.77)\end{array}$ & \\
\hline lscore & & $\begin{array}{l}-0.003^{* *} \\
(-1.99)\end{array}$ \\
\hline anano & $\begin{array}{c}-0.051^{* * * *} \\
(-3.26)\end{array}$ & $\begin{array}{c}-0.038 * * \\
(-2.27)\end{array}$ \\
\hline size & $\begin{array}{c}-0.044 * * * \\
(-3.07)\end{array}$ & $\begin{array}{c}-0.033 * * \\
(-2.18)\end{array}$ \\
\hline open & $\begin{array}{l}-0.027 \\
(-0.91)\end{array}$ & $\begin{array}{l}-0.015 \\
(-0.46)\end{array}$ \\
\hline lev & $\begin{array}{l}0.339 * * * \\
(4.21)\end{array}$ & $\begin{array}{c}0.339 * * * \\
(3.85)\end{array}$ \\
\hline insshare & $\begin{array}{c}-0.234^{* * *} \\
(-3.80)\end{array}$ & $\begin{array}{c}-0.238 * * * \\
(-3.61)\end{array}$ \\
\hline duality & $\begin{array}{l}-0.012 \\
(-0.36)\end{array}$ & $\begin{array}{l}0.011 \\
(0.29)\end{array}$ \\
\hline assurance & $\begin{array}{l}0.119 \\
(1.44)\end{array}$ & $\begin{array}{l}0.104 \\
(1.29)\end{array}$ \\
\hline year & control & control \\
\hline observations & 1,386 & 1,125 \\
\hline $\begin{array}{c}\text { number of } \\
\text { stock }\end{array}$ & 619 & 497 \\
\hline r2 & - & • \\
\hline $\mathrm{p}$ & 0 & $1.14 \mathrm{E}-10$ \\
\hline
\end{tabular}

z-statistics in parentheses

$* * * \mathrm{p}<0.01, * * \mathrm{p}<0.05, * \mathrm{p}<0.1$ 
Table 9

\begin{tabular}{|c|c|c|}
\hline variables & $\begin{array}{l}\text { model(5) } \\
\text { optimism }\end{array}$ & $\begin{array}{l}\text { model(6) } \\
\text { optimism }\end{array}$ \\
\hline constant & $\begin{array}{l}0.008 \\
(0.51)\end{array}$ & $\begin{array}{l}0.021 \\
(1.43)\end{array}$ \\
\hline score & $\begin{array}{l}-0.000 \\
(-1.64)\end{array}$ & \\
\hline lscore & & $\begin{array}{l}-0.000 * * \\
(-2.07)\end{array}$ \\
\hline anano & $\begin{array}{l}-0.001 \\
(-1.22)\end{array}$ & $\begin{array}{l}-0.000 \\
(-0.30)\end{array}$ \\
\hline size & $\begin{array}{l}-0.000 \\
(-0.52)\end{array}$ & $\begin{array}{l}-0.001 \\
(-1.24)\end{array}$ \\
\hline open & $\begin{array}{l}0.004 * * \\
(2.54)\end{array}$ & $\begin{array}{l}0.001 \\
(0.76)\end{array}$ \\
\hline lev & $\begin{array}{c}0.031^{* * *} \\
(7.21)\end{array}$ & $\begin{array}{c}0.028 * * * \\
(6.47)\end{array}$ \\
\hline insshare & $\begin{array}{l}0.001 \\
(0.38)\end{array}$ & $\begin{array}{l}0.000 \\
(0.02)\end{array}$ \\
\hline duality & $\begin{array}{l}0.001 \\
(0.74)\end{array}$ & $\begin{array}{l}-0.000 \\
(-0.02)\end{array}$ \\
\hline assurance & $\begin{array}{l}0.001 \\
(0.20)\end{array}$ & $\begin{array}{l}0.003 \\
(0.78)\end{array}$ \\
\hline year & control & control \\
\hline observations & 1,386 & 1,125 \\
\hline $\begin{array}{c}\text { number of } \\
\text { stock }\end{array}$ & 619 & 497 \\
\hline r2 & . & . \\
\hline $\mathrm{p}$ & 0 & 2.65E-09 \\
\hline
\end{tabular}

\section{Conclusions}

Our study provides empirical evidence in support of the recently literatures emphasized on csr disclosure effect on analyst forecast. We find that csr disclosure quality contributes to decrease analyst forecast error and optimism; furthermore, the effect of csr disclosure quality in previous year is more significant than contemporaneous csr disclosure quality on decreasing analyst forecast error and optimism.

We provide a great deal of evidence to support random effect is superior to fixed effect and pooled ols in our empirical analyses carried out f-test, bp-lm test and hausman test, which is inconsistent with prior studies. The results indicate individual effects are supposed to be considered during panel data processing. There is existing huge heterogeneity in our samples in spite of using cluster robust standard errors. We survey sample firms published csr reports in our sample in order to find the heterogeneity. We find that prior studies applied fixed effect model or pooled ols model focus on single capital market. We apply random effect model owing to multi-level capital markets in China. There are three levels capital markets, which are main board, small and medium enterprises (sme) board and growth enterprises market board (gem) board, to serve diverse investors and financiers. Gem board caters in 2009 largely to funding requirements of technology and 
innovation-oriented start-up firms. Sme board and gem board are hailed as an important component of China's multi-tier capital market system, which wide investment channels, stimulate enthusiasm for entrepreneurship and boost private investment. Also they play a critical role in adjusting to the economic structure and shifting growth model. Listed companies in main board, sme board and gem board observe completely distinct listing restrictions and transaction systems. In our analysis, aiming to emphasize the phenomenon that more and more listed companies in China disclose corporate social responsibility information, we include all the listed firms belonging to different boards in capital markets. Samples distributed in multi-level capital markets cause the heterogeneity generally and impact the choice of methodology.

Overall, our results provide evidence consistent with our hypotheses that the effect of csr disclosure quality in previous year is stronger than in current year on analyst forecast and estimate that random effect model is superior to fixed effect model and pooled ols model in multi-level capital markets in China.

\section{References}

[1]B. E. Ashforthand, F. Mael, Social identity theory and the organization. Academy of management review, 14(1989) 20-39.

[2]X. Y. Bai, Multiple impact of listed corporate disclosure policy on analyst forecast. Journal of Financial Research(2009)92-112. (in Chinese)

[3]S. P. Baginski, J. M. Hassell, The market interpretation of management earnings forecasts as a predictor of subsequent financial analyst forecast revision. Accounting Review, (1990)175-190.

[4]R. A. Baron, G. D. Markman,Beyond social capital: how social skills can enhance entrepreneurs' success. The academy of Management Executive, 14(2000)106-116.

[5]O. E. Barron, C. O. Kile, and T. B. O'KEEFE, MD\&A quality as measured by the sec and analysts' earnings forecasts. Contemporary Accounting Research, 16(1999)75-109.

[6]B. K. Behn, J. H. Choi,and T. Kang, Audit quality and properties of analyst earnings forecasts. The Accounting Review, 83(2008) 327-349.

[7]R. Bhushan, Firm characteristics and analyst following. Journal of Accounting and Economics, 11(1989) 255-274.

[8]J. L. Blazovich, L. Murphy Smith, Ethical corporate citizenship: does it pay?. In Research on professional responsibility and ethics in accounting (2011)127-163.

[9]C. A. Botosan, Disclosure level and the cost of equity capital. The Accounting review, 72(1997)323-349.

[10]Boudreau, J. W., Rynes, S. L. Role of recruitment in staffing utility analysis. Journal of Applied Psychology, 70(1985) 354.

[11]M. T. Bradshaw, How do analysts use their earnings forecasts in generating stock recommendations?. The Accounting Review, 79 (2004)25-50.

[12]L. D. Brown, K. J. Kim, Timely aggregate analyst forecasts as better proxies for market earnings expectations. Journal of Accounting Research, (1991)382-385.

[13]T. J. Brown, P. A. Dacin, The company and the product: corporate associations and consumer product responses. The Journal of Marketing,61(1997) 68-84.

[14]M. J. Brennan, P. J. Hughes, Stock prices and the supply of information. The Journal of Finance, 46 (1991)1665-1691.

[15]K. C. Butler, L. H. Lang, The forecast accuracy of individual analysts: evidence of systematic optimism and pessimism. Journal of Accounting Research, 29(1991)150-156.

[16]T. G. Calderon, Predictive properties of analysis' forecasts of corporate earnings. The Mid-Atlantic Journal of Business, 29 (1993) 41.

[17]X. Chen, Q. Cheng and K. Lo, On the relationship between analyst reports and corporate disclosures: exploring the roles of information discovery and interpretation. Journal of Accounting and Economics, 49(2010)206-226.

[18]V. K. Chopra, Why so much error in analysts' earnings forecasts?. Financial Analysts Journal, (1998)35-42. 
[19]S. Cleary, The relationship between firm investment and financial status. The Journal of Finance, 54(1999) 673-692.

[20]D. W. Collins, G. Gong and P. Hribar, Investor sophistication and the mispricing of accruals. Review of Accounting Studies, 8(2003)251-276.

[21]J. Conlisk, Why bounded rationality?. Journal of economic literature, 34(1996)669-700.

[22]V. Covrig, B.S. Low, The relevance of analysts' earnings forecasts in japan. Journal of Business Finance\&Accounting, 32(2005) 1437-1463.

[23]T. Crichfield, T. Dyckman and J. Lakonishok, An evaluation of security analysts' forecasts. Accounting Review, (1978)651-668.

[24]N. Darnall, I. Seol and J. Sarkis, Perceived stakeholder influences and organizations' use of environmental audits. Accounting, Organizations and Society, 34(2009)170-187.

[25]W. F. De Bondt, R. H. Thaler, Do security analysts overreact?. The American Economic Review, 80(1990)52-57.

[26]D. S. Dhaliwal, O. Z. Li , A. Tsang and Y. G. Yang, Voluntary nonfinancial disclosure and the cost of equity capital: the initiation of corporate social responsibility reporting. The Accounting Review, 86(2011)59-100.

[27]D. S. Dhaliwal, S. Radhakrishnan, A. Tsang and Y. G. Yang, Nonfinancial disclosure and analyst forecast accuracy: international evidence on corporate social responsibility disclosure. The Accounting Review, 87(2012)723-759.

[28]R. J. Dowen, The relation of firm size, security analyst bias, and neglect. Applied Economics, 21(1989)19-23.

[29]A. Duru, D. M. Reeb, International diversification and analysts' forecast accuracy and bias. The Accounting Review, 77(2002)415-433.

[30]A. Edmans, Does the stock market fully value intangibles? employee satisfaction and equity prices. Journal of Financial Economics, 101(2011) 621-640.

[31]S. M. El-Gazzar, Predisclosure information and institutional ownership: a cross-sectional examination of market revaluations during earnings announcement periods. Accounting Review, (1998)119-129.

[32]E. F. Fama, Efficient capital markets: a review of theory and empirical work. The journal of Finance, 25(1970)383-417.

[33]C. Fieseler, On the corporate social responsibility perceptions of equity analysts. Business Ethics: A European Review, 20(2011)131-147.

[34]R. Fisman, G. Heal and V. Nair, A model of corporate philanthropy. Columbia University and University of Pennsylvania. Working Paper, (2006)1-23.

[35]R. Frankel, S. P. Kothari and J. Weber, Determinants of the informativeness of analyst research. Journal of Accounting and Economics, 41(2006) 29-54.

[36]Fried, D., Givoly, D. Financial analysts' forecasts of earnings: a better surrogate for market expectations. Journal of Accounting and Economics, 4(1982) 85-107.

[37]M. Friedman, The social responsibility of business is to increase its profits. The New York Times Magazine, (1970) 1-6.

[38]D. S. Gelb, J. A. Strawser, Corporate social responsibility and financial disclosures: an alternative explanation for increased disclosure. Journal of Business Ethics, 33(2001)1-13.

[39]J. R. Graham, C. R. Harvey, The long-run equity risk premium. Finance Research Letters, 2(2005)185-194.

[40]P. Gugler, J. Y. Shi, Corporate social responsibility for developing country multinational corporations: lost war in pertaining global competitiveness?. Journal of Business Ethics, 87(2009)3-24.

[41]P. M. Healy, A. P. Hutton and K. G. Palepu, Stock performance and intermediation changes surrounding sustained increases in disclosure. Contemporary accounting research, 16 (1999)485-520.

[42]P. M. Healy, K. G. Palepu, Information asymmetry, corporate disclosure, and the capital markets: a review of the empirical disclosure literature. Journal of accounting and 
economics, 31 (2001) 405-440.

[43]D. R. Herrmann, O. K. Hope and W. B. Homas, International diversification and forecast optimism: the effects of reg fd. Accounting Horizons, 22(2008)179-197.

[44]M. E. Holbrook, Corporate social responsibility and earnings predictability. International Journal of the Academic Business World, 8 (2014)37-50.

[45]L. Holder-Webb, J. R. Cohen, L. Nath and D. Wood, The supply of corporate social responsibility disclosures among US firms. Journal of business ethics, 84(2009)497-527.

[46]J. Holland, U. Johanson, Value - relevant information on corporate intangibles - creation, use, and barriers in capital markets - "between a rock and a hard place" . Journal of Intellectual Capital, 4 (2003) 465-486.

[47]H. Hong, J. D. Kubik, Analyzing the analysts: career concerns and biased earnings forecasts. The Journal of Finance, 58(2003)313-351.

[48]O. K. Hope, Disclosure practices, enforcement of accounting standards, and analysts' forecast accuracy: an international study. Journal of Accounting Research, 41(2003)235-272.

[49]I. Ioannou, G. Serafeim, The impact of corporate social responsibility on investment recommendations. Academy of Management,1(2010) 1-6.

[50]I. Ioannou, G. Serafeim, The impact of corporate social responsibility on investment recommendations: analysts' perceptions and shifting institutional logics. Strategic Management Journal, 36 (2015)1003-1081.

[51]R. Jennings, Unsystematic security price movements, management earnings forecasts, and revisions in consensus analyst earnings forecasts. Journal of Accounting Research, 25(1987)90-110.

[52]H. Jo, M. Harjoto,Analyst coverage, corporate social responsibility, and firm risk. Business Ethics: A European Review, 23(2014) 272-292.

[53]K. Kadous, S. D. Krische and L. M. Sedor, Using counter-explanation to limit analysts' forecast optimism. The Accounting Review, 81(2006)377-397.

[54]C. Kang, F. Germann and R. Grewal, Washing away your sins? corporate social responsibility, corporate social irresponsibility, and firm performance. Journal of Marketing, 80(2016)59-79.

[55]I. Kim, M. Venkatachalam, Are sin stocks paying the price for accounting sins?. Journal of Accounting, Auditing \& Finance, 26 (2011)415-442.

[56]A. Klein, Audit committee, board of director characteristics, and earnings management. Journal of accounting and economics, 33(2002)375-400.

[57]W. Kross, B. Ro and D. Schroeder, Earnings expectations: the analysts' information advantage. The Accounting Review, 65(1990)461-476.

[58]L. Lang, E. Ofek and R. Stulz, Leverage, investment, and firm growth. Journal of financial Economics, 40(1996)3-29.

[59]M. H. Lang, Discussion of "stock performance and intermediation changes surrounding sustained increases in disclosure”. Contemporary Accounting Research, 16 (1999)521-524.

[60]M. H. Lang, K. V. Lins and D. P. Miller, ADRs, analysts, and accuracy: does cross listing in the united states improve a firm's information environment and increase market value?. Journal of Accounting Research, 41(2003)317-345.

[61]M. H. Lang, R. J. Lundholm, Corporate disclosure policy and analyst behavior. The Accounting Review,71(1996)467-492.

[62]M. H. Lang, R. J. Lundholm, Voluntary disclosure and equity offerings: reducinginformation asymmetry or hyping the stock?. Contemporary accounting research, 17 (2000)623-662.

[63]B. Lee, J. O'Brien and K. Sivaramakrishnan, An analysis of financial analysts' optimism in long-term growth forecasts. The Journal of Behavioral Finance, 9(2008)171-184.

[64]B. Lev, C. Petrovits and S. Radhakrishnan, Is doing good good for you? how corporate charitable contributions enhance revenue growth. Strategic Management Journal(2009)182-200.

[65]W. J. Li, L. ZHang, Nonfinancial Disclosure and Analyst Forecast Accuracy: Empirical Evidence On Corporate Social Responsibility Disclosure From Shenzhen Stock 
Exchange,The theory and practice of finance and economics 35(2014)69-74.(in Chinese)

[66]J. Livnat, Y. Zhang, Information interpretation or information discovery: which role of analysts do investors value more?. Review of Accounting Studies, 17(2012) 612-641.

[67]A. Ljungqvist, F. Marston, L. T. Starks, K. D. Wei and H. Yan, Conflicts of interest in sell-side research and the moderating role of institutional investors. Journal of Financial Economics, 85(2007) 420-456.

[68]J. B. McGuire, A. Sundgren and T. Schneeweis, Corporate social responsibility and firm financial performance. Academy of management Journal, 31(1988)854-872.

[69]A. McWilliams, D. Siegel, Corporate social responsibility: a theory of the firm perspective. Academy of management review, 26(2001)117-127.

[70]D. C. Nichols, M. M. Wieland, Do firms' nonfinancial disclosures enhance the value of analyst services?. (2009) working paper.

[71]P. C. O'Brien, Analysts' forecasts as earnings expectations. Journal of Accounting and Economics, 10(1988)53-83.

[72]P. C. O'Brien, R. Bhushan, Analyst following and institutional ownership. Journal of Accounting Research, (1990)55-76.

[73]J. D. Piotroski, D. T. Roulstone, The Influence of Analysts, Institutional Investors, and Insiders on the Incorporation of Market, Industry, and Firm-Specific Information into Stock Prices. The Accounting Review,79(2004)1119-1151.

[74]P. L. Rechner, D. R. Dalton, CEO duality and organizational performance: a longitudinal analysis. Strategic Management Journal, 12 (1991)155-160.

[75]C. Rhianon Edgley, M. J. Jones and J. F. Solomon, Stakeholder inclusivity in social and environmental report assurance. Accounting, Auditing \& Accountability Journal, 23(2010)532-557.

[76]P. W. Roberts, G. R. Dowling, Corporate reputation and sustained superior financial performance. Strategic management journal, 23(2002)1077-1093.

[77]R. Simnett, A. Vanstraelen and W. F. Chua, Assurance on sustainability reports: an international comparison. The accounting review, 84 (2009)937-967.

[78]K. T. Trotman, G. W. Bradley, Associations between social responsibility disclosure and characteristics of companies. Accounting, organizations and society, 6(1981)355-362.

[79]A. Vanstraelen, M. T. Zarzeski and S. W. Robb, Corporate nonfinancial disclosure practices and financial analyst forecast ability across three european countries. Journal of International Financial Management \& Accounting, 14(2003) 249-278.

[80]H. Wang, L. Tong, R. Takeuchi and G. George, Corporate social responsibility: an overview and new research directions thematic issue on corporate social responsibility. Academy of Management Journal, 59(2016)534-544.

[81]G. Waymire, Additional evidence on the accuracy of analyst forecasts before and after voluntary management earnings forecasts. Accounting Review, 61(1986)129-142.

[82]M. Welker, Disclosure policy, information asymmetry, and liquidity in equity markets. Contemporary accounting research, 11(1995)801-827.

[83]J. J. Wild, S. S. Kwon, Earnings expectations, firm size, and the informativeness of stock prices. Journal of Business Finance \& Accounting, 21 (1994)975-996.

[84]P. A. Williams, The relation between a prior earnings forecast by management and analyst response to a current management forecast. Accounting Review, 71(1996)103-115.

[85]M. F. Wong, X. F. Zhang, CEO optimism and analyst forecast bias. Journal of Accounting, Auditing \& Finance, 29(2014)367-392.

[86]C. C. Yeh, L. Kuo and H. C. Yu, Disclosure of corporate social responsibility and value creation: evidence from China. Transnational Corporations Review, 3(2011) 34-50.

[87]C.-Y. Yoo, J. Pae, Corporate charitable contributions: business award winners' giving behaviors. Business Ethics: A European Review, 25(2016)25-44.

[88]M. Yu, Analyst following, corporate governance and valuation: emerging-market evidence. Journal of Applied Business Research, 25(2009)67-76. 
[89]J. Zhang, E. C. Lin and H. Shin, S\&P 500 index inclusions and analysts' forecast optimism. The Journal of Investing, 19(2010)50-57. 